\title{
CREATIVE ECONOMIC DEVELOPMENT IN ECONOMIC EDUCATION PERSPECTIVE
}

\author{
Daryono $^{1 *}$, Sugeng Wahyudi ${ }^{2}$, Suharnomo $^{3}$, Indi Djastuti ${ }^{4}$, Mahfudz $^{5}$, Amie \\ Kusumawardhani $^{6}$, Sri Supriyati ${ }^{7}$ \\ ${ }^{1}$ Faculty of Economics and Business, Universitas Jenderal Soedirman \\ ${ }^{2}$ Faculty of Economics and Business, Diponegoro University. \\ ${ }^{3}$ Faculty of Economics and Business, Diponegoro University \\ ${ }^{4}$ Faculty of Economics and Business, Diponegoro University \\ ${ }^{5}$ Faculty of Economics and Business, Diponegoro University \\ ${ }^{6}$ Faculty of Economics and Business, Diponegoro University \\ ${ }^{7}$ Faculty of Economics and Business, Diponegoro University
}

\begin{abstract}
This study aims to determine the effect of entrepreneurial knowledge on creative attitudes of creative economy sub-sector Small Medium Enterprises in Kendal sub-district in the context of creative economic development. The population in this study were 129 Micro Small Medium Enterprises in the creative industry subsector. The total sample in this study was as many as 33 Micro Small Medium Enterprises in the creative industry subsector. The results of this study indicate that entrepreneurial knowledge has a positive and significant influence on the creative attitude of creative economy sub-sector Micro Small Medium Enterprises in Kendal sub-district, Central Java City, Indonesia.
\end{abstract}

\section{INTRODUCTION}

The informal sector has a strategic role in economic development, especially in overcoming poverty and unemployment. This also relates to the role of economic education in the informal sector through the transformation of the values and character of entrepreneurship in business activities. The informal sector is dominated by micro, small, and medium enterprises (MSMEs). Some research results show that business actors in the informal sector are dominated by MSMEs, both in developing countries and in developed countries (Gurtoo and Williams, 2009, Schneider and Williams, 2013, Webb et al., 2009, Williams, 2009a, Williams, 2009b, Williams, 2009c, Williams, 2010).

The informal sector is dominated by MSMEs. The development and contribution of the MSME sector is inseparable from the growing growth of new entrepreneurs in the community. The trend of the emergence of entrepreneurship is due to economic pressure, so that someone is forced to create their own jobs. In addition, there are other factors, namely unemployment, frustration of previous jobs, and the need for decent living. Current trends in the development of MSMEs in Indonesia are mostly directed at the creative economy sector which is largely determined by human capital.

The most important asset in the global era is human capital. A nation that has comparative advantages in natural resources will not do much in the arena of global compe ${ }^{*}$ tition without being supported by the excellence of human capital. Only a nation

* Corresponding author: daryonojvc@gmail.com 
that excels in human capital will be able to take part and master knowledge and its application in the real form of problem solvers encountered in life (Thomas et al., 2013).

The concept of creative economy is an economic concept based on human abilities and skills. Human civilization is divided into three economic waves. A paradigm shift in economic development cannot be separated from changes in global scale. This change was marked by a shift in economic development from the agricultural, industrial, and information sectors to the creative economy sector. The development of the creative economy sector of a nation will compete and have an impact on social life if managed properly. Therefore, the rise of a new economic wave requires innovation and creativity of the community, so that the quality of human resources is needed as creative economic actors. This condition must be linked to the ability to manage potential. Therefore, the concept of creative economy must be in accordance with the ability of innovation and creativity in managing existing local potential.

The development of the creative economy cannot be separated from the development of the creative industry because the development of the creative economy requires the support of the economic industry. The development of the creative economy is believed to be a way for developing countries to follow the development of the global economy. This is because the creative economy sector relies more on creativity and intellectual community in developing existing local potential. On the other hand, the development of a creative economy in a particular-place depends heavily on the quality of human resources in developing the creativity of an intelligence. In other words, the development of creative economy is an alternative economic activity for the community in developing their potential (United Nations Development Programme, 2013).

This explanation can show that economic change is determined by the quality of human resources in exploring creativity as innovation as the main impetus in developing a creative economy. Therefore, if the community has innovation and creativity, the acceleration of economic development will be faster. Therefore, the choice in developing a creative economy will increase competitive business. The development of the creative economy sector must also be oriented to the cultural aspects of society. Therefore, the development of profitable economic sectors will have an impact on the rise of community-driven business opportunities. Therefore, structured and systematic development will encourage the development of this sector in the region. According to the explanation, it shows that creativity arising from cultural wealth will create jobs. Therefore, with the development of the creative economy, it will increase the income of the community (Hamilton, 2009, Cunningham and Higgs, 2008).

One of the sub-districts in Central Java City which is identical with the creative economy is Kendal sub-district. Kendal sub-district is the centre of Central Java's creative economy area. With a variety of potential, such as the number of hotels that are ready to accommodate tourists, as well as malls and markets as a strategic location to market creative products, it becomes a strength for Kendal sub-district in empowering the economy of the community through creative economic development programs. In Kendal subdistrict, there are 71 hotels that are ready to become supporting facilities for the marketing of creative products, so that they can build a positive image for Kendal sub-district through tourism facilities. There are 129 creative zones in Kendal sub-district in 2016. 
Table 1

Creative Zone Data for 2016

\begin{tabular}{lc}
\hline \multicolumn{1}{c}{ Creative Industries Subsector } & Number of Business Actors \\
\hline Interior design & 5 \\
Clothes & 55 \\
Art & 28 \\
Performing Arts & 1 \\
Publishing and printing & 4 \\
Culinary & 36 \\
\hline Total & 129 \\
\hline
\end{tabular}

Source: Creative Zone of Kendal Sub-district in 2016

Empirical facts show that the majority creative products in the Kendal sub-district are produced by MSMEs included into the informal category. The informal sector MSMEs still have number of problems, some of which include low levels of creativity and innovation because of lack of knowledge. The lack of creative attitudes results in low innovative attitudes, achievement motivation, orientation in profit, perseverance and fortitude, determination of hard work, having a strong drive, energetic, and initiative.

Knowledge aspects are important in the era of creative economy. The study results of Hasan (2012) regarding the characteristics of small-scale industrial labour shows that workers in small-scale industries in Central Java City have the characteristics of utilizing their economic knowledge, both obtained formally and informally in carrying out production activities. Other findings from Hasan (2014) related to productivity and elasticity of industrial sector employment opportunities show that knowledge and education are one of the most important aspects in determining economic behaviour, especially those related to employment opportunities and other economic decisions.

Based on this, the development of the creative economy in the perspective of economic education is a study that needs to be done because economic education is one of the efforts to foster a creative economy in Kendal sub-district. The development of the creative economy in the perspective of economic education is carried out in the form of knowledge transfer, both formally, non-formally, and informally. Transferred knowledge as an effort to increase innovation and creativity of MSMEs engaged in the creative economy is divided into two, namely tacit and explicit. The character of tacit knowledge is constructed from individual experience and is a basic form of explicit knowledge. Tacit knowledge represents knowledge possessed by a person, attached to the mind, and cannot be separated from the person who owns it. As consequence, tacit knowledge is difficult to transfer. Explicit knowledge is knowledge that is easily changed in formal and systematic language so that it is easier to transfer than tacit knowledge.

Based on this, it can be stated that the transfer of knowledge in the development of the creative economy carried out is realized in the aspect of entrepreneurial knowledge related to creative attitudes. Entrepreneurial knowledge consists of the variable of knowledge of entrepreneurship with the indicators are knowledge of business planning, knowledge of decision making, knowledge of managing the company, knowledge of managing finances, knowledge of production techniques/processes, knowledge of designing products, knowledge of marketing techniques, knowledge of distributing goods, knowledge of accounting administration, and technical knowledge of controlling the company.

While the variable of creative attitude, referring to the creativity level theory of McGregor (2008) is a creative process dimension whose indicators are fluency in thinking, originality in thinking, and flexibility in thinking. Based on this, the hypothesis of this study is knowledge of entrepreneurship has a positive effect on creative attitude. 


\section{METHOD}

This research is quantitative research. The data used in this study were sourced from the SME industry subsector in the creative industry in Central Java. The types of data in this study include primary data and secondary data. Primary data was obtained through questionnaires and direct interviews with respondents regarding economic education and creative economic development, especially those related to the variable of knowledge of entrepreneurship and creative attitudes. Whereas secondary data was obtained from the Creative Economy Agency, namely the number and distribution of creative economy subsector MSMEs in Kendal sub-district as well as data in the form of other documentation relating to research problems.

The population in this study are all business actors who are engaged in the creative economy in Kendal sub-district as many as 129 SMEs in the creative industry sub-sector. Sampling was determined by using purposive sampling technique, the aim was to capture a truly representative sample with the study, so obtained as many as 33 creative industries sub-sector MSMEs in the sub-district of Kendal. The data analysis technique used in this study is multiple linear regression through the SPSS version 21 program.

\section{RESULT AND DISCUSSION}

A summary of research results can be seen in Table 1. Based on the results of data processing through the SPSS Version 21 program, the regression equation $\mathrm{Y}=2,861+$ $7,199 \mathrm{X} 1+\mathrm{e}$ is obtained. This equation shows that entrepreneurial knowledge has a positive influence on creative attitudes. This means that if knowledge increases, it will also increase creative attitudes. The contribution of entrepreneurial knowledge to the creative attitude of creative industry sub-sector MSME actors in Central Java City was 54.2 percent, while the remaining 45.8 was the contribution of other variables not included in the research model.

Table 2

Estimation Results

\begin{tabular}{lcccc}
\hline $\begin{array}{l}\text { Independent } \\
\text { Variable and } \\
\text { Constant }\end{array}$ & $\begin{array}{c}\text { Regression } \\
\text { Coefficient }\end{array}$ & $\begin{array}{c}\text { Standard of } \\
\text { Error }\end{array}$ & $\mathbf{t}_{\text {count }}$ & Significance \\
\hline Constant & 2.861 & 5.371 & 1.701 & 0.041 \\
Entrepreneurial & 7.199 & 0.142 & 5.504 & 0.041 \\
Knowledge & & & & \\
\hline *Level of confidence $\alpha=5 \%$ & & & \\
R Square $=0.542$ & & & & \\
\hline
\end{tabular}

The results of the significance test through the $t$ test using SPSS Version 21 can be seen in Table 2. The results of data processing show that entrepreneurial knowledge has a significant influence on the creative attitude of the creative industry sub-sector MSMEs in Central Java City.

Table 3

Significance Test

\begin{tabular}{lcccc}
\hline $\begin{array}{l}\text { Independent } \\
\text { Variable }\end{array}$ & $\mathbf{t}_{\text {count }}$ & Significance & $\begin{array}{c}\text { Significant } \\
\text { Level }\end{array}$ & Conclusion \\
\hline Constant & 1.701 & 0.041 & 0.05 & Significant \\
Entrepreneurial & 5.504 & 0.041 & 0.05 & Significant \\
Knowledge & & & & \\
\hline
\end{tabular}


The findings of this study indicate that entrepreneurial knowledge has a significant influence on the creative attitudes of SMEs in the creative industry sub-sector in Central Java City. Entrepreneurial knowledge refers to an individual's appreciation of the concepts, skills, and mentality expected of an entrepreneur. This knowledge can be obtained and developed through entrepreneurial activities, which in this case is an entrepreneurial activity carried out by creative industry sub-sectors in the city of Central Java. The findings of this study are in line with studies identifying types of entrepreneurial knowledge that complement each other in producing creative attitudes. This type of knowledge relates to an individual's ability to recognize entrepreneurial opportunities that involve discovery and innovation.

The ability of creative industry sub-sectors MSMEs in the city of Central Java to achieve certain successes is influenced by entrepreneurial factors. The implications of the application of the concept of entrepreneurship itself in business organizations stated that if entrepreneurs want to succeed in the face of open competition in the current global era must have a creative and innovative entrepreneurial spirit, especially seeing the current conditions of course it takes modern entrepreneurs, who have more insight, thinking ahead, always following developments, and open to new concepts and ideas. With a far-sighted outlook, always working and being intentional, creating something new, open to new experiences, including being dissatisfied with what is done now is the side of success in carrying out its business activities related to its competence. The determinants of success are entrepreneurial competencies, in this case, creativity and innovation as determinants that are the characteristics of entrepreneurship which are implied from the entrepreneurial knowledge gained.

In connection with the relationship with entrepreneurial knowledge, creative attitude is the unification of knowledge from various fields of different experiences to produce new and better ideas. Creativity is also a producer of new ideas and innovations as translators of new ideas into new companies, new products, new services, new processes, or new methods of production. Research findings that show the presence of influence between entrepreneurial knowledge on creative attitudes are in line with some previous literature and research. Creative attitude is the core of entrepreneurial knowledge (Wood and McKinley, 2010). Creative entrepreneurs will always work hard and continuously to improve ideas and solutions, by making gradual changes and improvements to their work.

\section{CONCLUSSIONS AND RECOMENDATIONS}

The results show that entrepreneurial knowledge has a significant influence on the creative attitudes of the MSMEs in the creative industry sub-sector in Central Java City. The results of this study have implications for the development of creative industry subsector MSMEs in Central Java City need to consider aspects of entrepreneurship education, both formal, non-formal, and informal, so that through education is formed entrepreneurial knowledge. Through this knowledge, it is expected that creative attitudes can be formed to realize the business success of the creative industry subsector MSMEs in Central Java City 


\section{REFERENCES}

1. Cunningham, S. D. \& Higgs, P. L. Creative Industries Mapping: Where Have We Come From and Where Are We Going? Creat. Ind. J. (1), 18-22 (2008).

2. Gurtoo, A. \& Williams, C. Entrepreneurship and the Informal Sector: Some Lessons from India. Int. J. Entrep. Innov. (10), 55-62 (2009).

3. Hamilon, L. Building the creative economy in Nova Scotia. The Research Committee of the Nova Scotia Cultural Action Network. 27-12 (2009).

4. Hasan. M. Characteristics of Small Indutrial Labor. J. Develop. Agric. Ec. (2) (2012).

5. McGregor, D. Thinking: developing learning. A guide to thinking skills in education, McGrawHill. (2008)

6. Schneider, F. \& Williams, C. C. The Shadow Economy (Instiute of Economic Affairs, London, 2013).

7. Thomas, H., Smith, R. R. \& Diez, F. Human Capital and Global Business Strategy (Cambridge University Press, New York, 2013)

8. Isar, Y. R., UNCTAD \& UNDP. Creative Economy Report 2013: Widening local development pathways. United Nations Development Programme and the United Nations Educational, Scientific and Cultural Organization (2013).

9. Webb, J. W., Tihanyi, L., Ireland, R. D. \& Sirmon, D. G. You say illegal, i say legitimate: Entrepreneurship in the informal economy. Academy of Management Review (2009).

10. Williams, C. C. Entrepreneurship and the off-the-books economy: Some lessons from England. Int. J. Manag. Enterp. Dev. (7), 429-444 (2009a)

11. Williams, C. C. The motives of off-the-books entrepreneurs: Necessity- or opportunitydriven? Int. Entrep. Manag. J. (5), 203-217 (2009b).

12. Williams, C. C. Beyond Necessity-Driven Versus Opportunity-Driven Entrepreneurship . Int. J. Entrep. Innov. (14), 44-60 (2008).

13. Williams, C. C. Spatial variations in the hidden enterprise culture: Some lessons from England. Entrep. Reg. Dev. (2010), 22, 403-423.

14. Wood, M. S. \& McKinley, W. The production of entrepreneurial opportunity: a constructivist perspective. Strateg. Entrep. J. (2010), 4,66-84. 